\title{
IMPACT OF BASKETBALL FAN BEHAVIOUR ON THE ORGANIZATION'S BRAND
}

\author{
Irena Valantinė, Ingrida Grigaliūnaitė, Lina Danilevičienė \\ Lithuanian Sports University, Kaunas, Lithuania
}

\begin{abstract}
Background. In recent years sports industry has been growing fast, changing trends forced organizations to be creative and look for different ways to increase the competitiveness. Sport has become a business that meets all key management principles (Paul, 2003). In order for an organization to be profitable it is important to have good governance and effective marketing to attract new customers (Fillis \& Mackay, 2014), in sports - fans that create added value for the clubs (Zagnoli \& Radicchi, 2010). Some authors argue that fans are not only consumers, but also co-creators of the final product (Richelieu \& Pons, 2011). The objective of this work was to measure the impact of basketball fan behaviour on the brand of sport organization.

Methods. To measure the impact of basketball fan behaviour on the brand of sports organization methodological triangulation was used in the study. The research consisted of 3 stages: questionnaire (Sandanski, Slavchev, \& Draganov, 2016), semi-structured interviewing I and semi-structured interviewing II. The study was partly conducted during the Erasmus+ Sport project "Fans Against Violence". In Lithuania the aforementioned project was conducted by the Lithuanian Basketball Federation in the partnership with association "Aktyvistai". 240 basketball fans from 5 different Lithuanian basketball clubs participated in the survey, 4 representatives from different basketball clubs and 4 fan leaders from different sport clubs were interviewed.

Results and conclusions. The majority of basketball fans that participated in the survey were men aged 20-24 years $(25.8 \%)$ and attended basketball matches by the guidance of hedonistic will $(13.5 \%)$. The same men became basketball fans encouraged by other fans $(25 \%)$. The strife between fans from different basketball teams goes from generation to generation and the main reason of aggressive behaviour is provocative actions from opposite fans $(15 \%)$ and alcohol consumption (11.4\%). While alcohol consumption is considered to be one of the main reasons to encourage fans' aggression, only a small percentage of the respondents were strongly against the use of alcohol (7\%). Summarizing all the results that were received during a semi-structured interviewing II it can be stated that the behaviour of the fans not only affects the brand of a basketball club, but is the main factor that impacts the brand of the club.
\end{abstract}

Keywords: brand, fans, aggression, basketball clubs.

\section{INTRODUCTION}

I $n$ recent years sport industry has been expanding rapidly, as a consequence sport became a business which applies all key management principles (Paul, 2003). It is no longer sufficient just to administer a sports organization, in order for the organization to be profitable an important factor is management and effective marketing complex (Fillis \& Mackay, 2014). In sports industry fans can be distinguished as main consumers (Hughson
\& Free, 2006). Some authors argue that fans are not only consumers, but they also contribute to the creation of the final product (Richelieu \& Pons, 2011).

The main difference between ordinary spectators and fans is the fact that spectator's interest in the club quickly fades away, while fans' interest only increases over time. Fans' attachment to the team due to various circumstances, social and 
economic reasons may vary. In research literature, a variety of sports fans' classification theories can be found which are based on the ground for which one becomes a fan (Fillis \& Mackay, 2014).

As can be seen in the scientific literature, sports fans are divided not only according to the devotion and attachment to the team, but also fans' relations with other fans as a group (Reysen \& Branscombe, 2010). One of the most detailed and the most developed classifications of fans is given by the scientists Hunt, Bristol and Bashaw (1999), which is based on individuals' motivational and behavioural differences. Classification distinguishes five types of fans: temporary, local, loyal-devoted, fanatical and dysfunctional. It can be assumed that fans' types are distinguished by the degree to which they identify themselves as supporters. Although there are many reasons why people are interested in sports, in the literature there are eight most common reasons distinguished which promote interest in sports: getaway, economic factors, eustress, selfesteem, group affiliation, entertainment, family, aesthetics (Wann, Grieve, Zapalac \& Pease, 2008).

Some authors argue that one of the ways to understand motives of the individual is personal values. One of the most popular scales of values is made by scientists Kahle, Duncan, Dalak and Aiken (2001). The scale consisted of eight distinguished values: self-esteem, security, relationships with others, self-realization, excitement, sense of belonging, respect, and pleasure. Depending on the type of fans and their identification with the team level, fan behaviour occurs in different forms: from passive support to anxious or even aggressive. In order to understand the behaviour of fans it is necessary to take into account the fact that fans are divided not only according to their level of interest in the team but also by the devotion to the team, self-identification within the team, motives and personal values. After analysing the literature, it can be noted that some types of fans, compared with others, are more prone to aggressive behaviour.

Madensen and Eck (2008) listed specific characteristics of venues, events, and staff that are related to higher levels of spectator violence (Figure 1).

Typically consumers already have a pre-formed opinion about a particular organization. Sport is complex and dynamic, and the image of it may vary depending on the emotion of the consumers. Consumers tend to create preliminary expectations of a sports organization and compare them with the results or experienced feeling. In this case, fans visit games hoping to win. It was found that the success of a team game leads fans to satisfaction, which encourages them to attend more matches, while a poor team performance leads to dissatisfaction and negative emotions, which not only reduces the match attendance, but may encourage aggressive behaviour (Beccarini \& Ferrand, 2006).

Aggression in sport is not a new phenomenon; in one form or another it has existed since sports began. Sometimes aggression occurs among the athletes during the match, sometimes between athletes and fans when the fans go beyond the limits and begin to threaten athletes, hurl degrading phrases or even show physical aggression. However, most of violence occurs among the fans (Swenson, 2012).

Aggressive behaviour can be two types: spontaneous and conscious (Pearson, 2008).
Figure 1. Spectator violence triangle and specific causes of spectator violence (Madensen \& Eck, 2008)

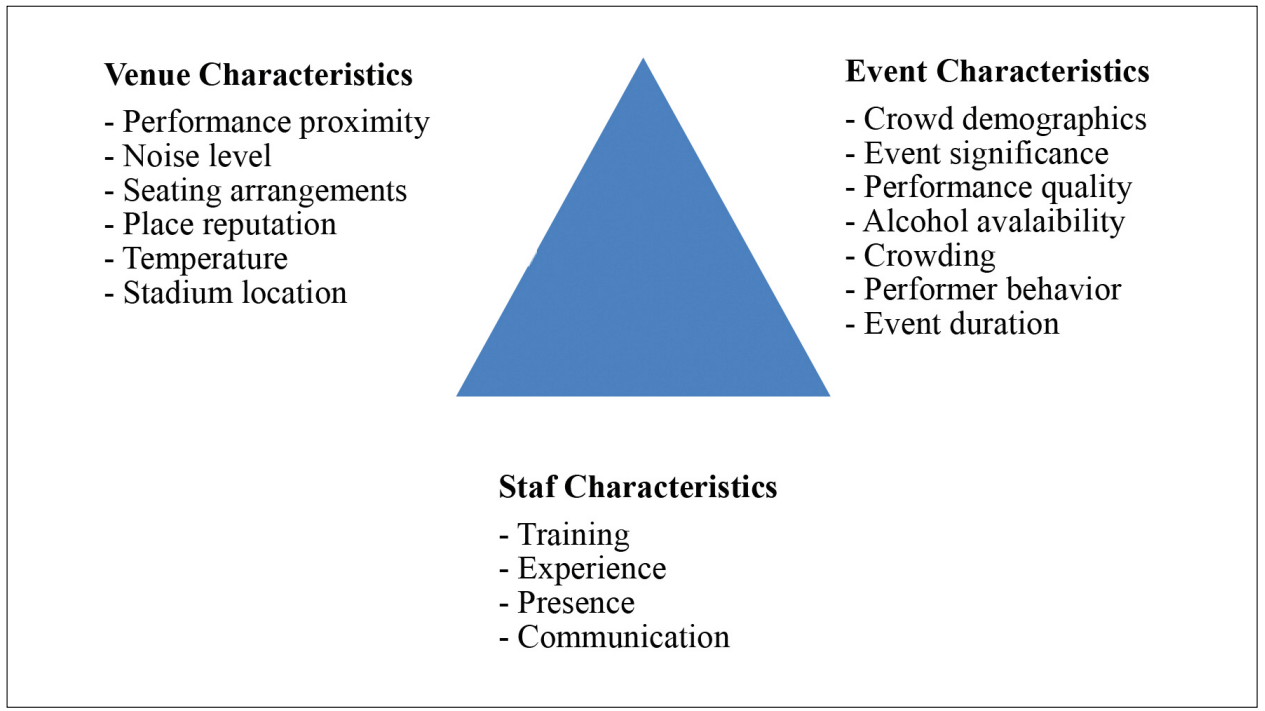


Conscious violence is planned and caused by an organized group of fans (Madensen \& Eck, 2008), while spontaneous aggression is often small-scale, usually caused by impulsive individuals (Shoham, Dalakas \& Lahav, 2015)).

Another frequently used aggression distribution theory was described by scientists Rahmati and Momtaz (2013). The theory distinguishes hostile and instrumental aggression. Hostile aggression is caused by anger or frustration; its sole purpose is to hurt something. Meanwhile, instrumental aggression, seeks to achieve other goals, such as change the decision of the umpire or distract athletes.

In literature, six distinguished most common forms of fan aggression can be found (Madensen \& Eck, 2008):

- Verbal - singing, chanting, and yelling taunts or obscenities;

- Gesturing - signalling to others with threatening or obscene motions;

- "Missile" throwing - throwing items such as food, drinks, bricks, bottles, broken seats, and cell phones at particular or random targets;

- Warming - rushing the field or stage and trying to crash the gates to gain entry, or rushing the exit, both of which may result in injury or death from trampling;

- Property destruction - knocking down sound systems, tearing up the playing field, and burning/damaging the venue or others' property;

- Physical - spitting, kicking, shoving, fistfights, stabbings, and shootings (Madensen \& Eck, 2008).
Image creation is important for each organization, thus researchers and practitioners are interested in this subject. Image is not simply a name; it is not solely a positioning statement nor is it the synthesis of marketing messages about the brand. It is fundamentally a promise made by a company to its consumers, a promise that must be supported by the company and sustained over the long-term (Carlson \& O'Cass, 2012).

In some cases, consumer uses club brand as a self-identification method by which they try to show others their hobbies or personalities (Richelieu \& Pons, 2011). When creating an image, it is important that image would be directed into the collective consciousness because individuals need recognition of the others as well as the feeling that they belong to a certain group. It can be concluded that the image is closely related to the prestige (Dima \& Vladutescu, 2012).

According to Richelieu and Pons (2011), organization constantly sends information to the consumers (advertising, word of mouth, reviews in the media, online forums). Lately, storytelling became one of the most common ways to create image. In this way, advertising professionals wrap brand with a story.

Sports industry mostly depends on the achieved results. Sports club image is mostly influenced by the athletes, sports and game results (Virvilaite \& Dilys 2015). Compared with other sectors of business, sports industry receives the most emotional response from their consumers, in this case - fans (Richelieu \& Pons, 2011). The relationship between the consumer and the club can

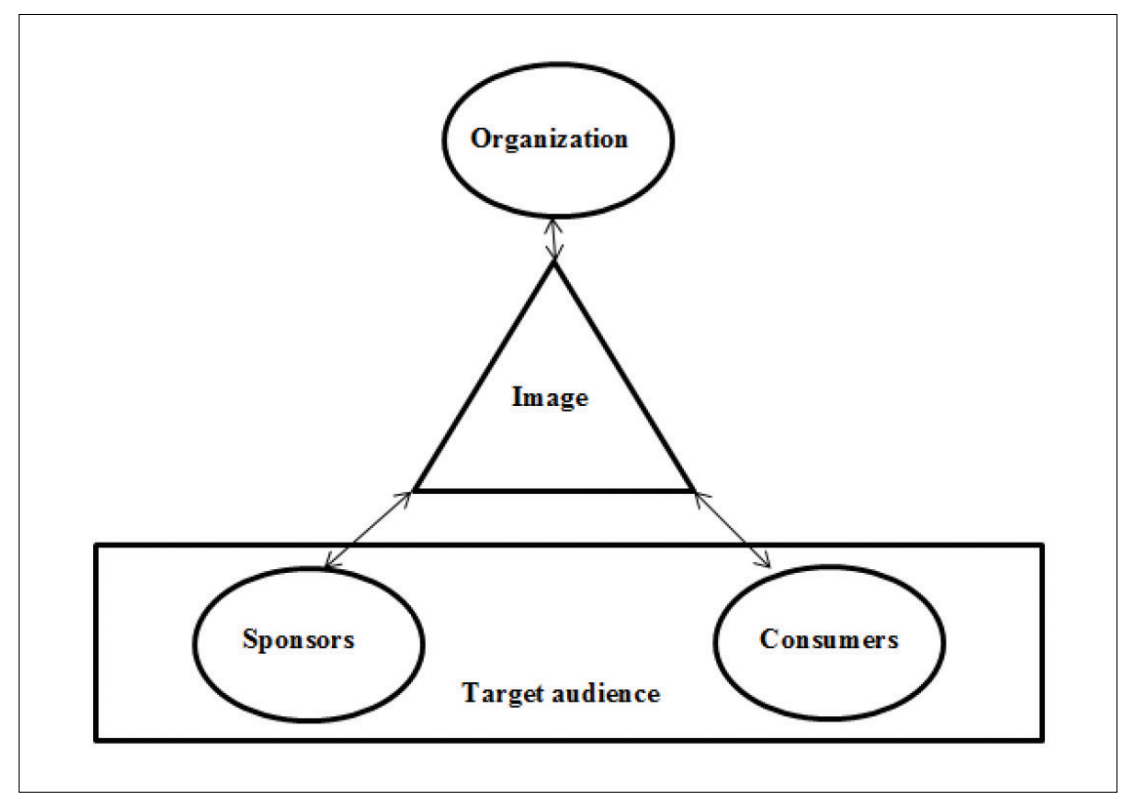


be called in various ways: faithfulness, devotion, loyalty or pride (Fillis \& Mackay 2014).

So that organization image could be formed efficiently, three interdependent agents are of great importantance: sports organization, sponsors and consumers.

Image of sports organizations is complex. It means that it consists of the image of the sport, the image of the team, the coach or the players' image. As an example, fans may like the team, but not a certain player, and vice versa (Hedlund, 2011).

Sponsors and fans are not just consumers, they are also one of the main agents creating the organization image. In the literature, fans are defined as co-creators and club representatives who not only enjoy the services they receive, but also contribute to building and branding team's image (Richelieu \& Pons, 2011). Spreading information about the club also is known as word of mouth (Laczniak, DeCarlo \& Ramaswami, 2001).

Fans' involvement in the formation of an image can be both positive and negative. Hedlund (2011) argues that it increases the total number of fans, creates a stronger link between the fans and strengthens commitment to the team. In the meantime, the negative consequences can be observed when fans shape a negative image about the team because of their violent behaviour. In summary, it can be concluded that the image is one of the key factors determining the success of any organization. Although there are many studies about the image or fans' violence, however fans' influence to the image is a relatively unexplored topic.

Research question. Does basketball fan behaviour influence basketball team's image?

\section{METHODS}

For the research methodological triangulation was applied (Figure 3). Triangulation is a number of different research methodologies and methods for the same phenomenon or process to investigate (Merriman, 1998; Stake, 2005; Yin, 2003).

Research partly conducted within the scope of the Erasmus+ Sport project "Fans against violence". International project "Fans against violence" was inspired by the Turkish Basketball Federation. In Lithuania this project was implemented by the Lithuanian Basketball Federation in conjunction with the association "Aktyvistai". The aim of the project was to unite different fan groups under
Figure 3. Study structure made by the authors based on Sandanski, Slavchev, and Draganov (2016)

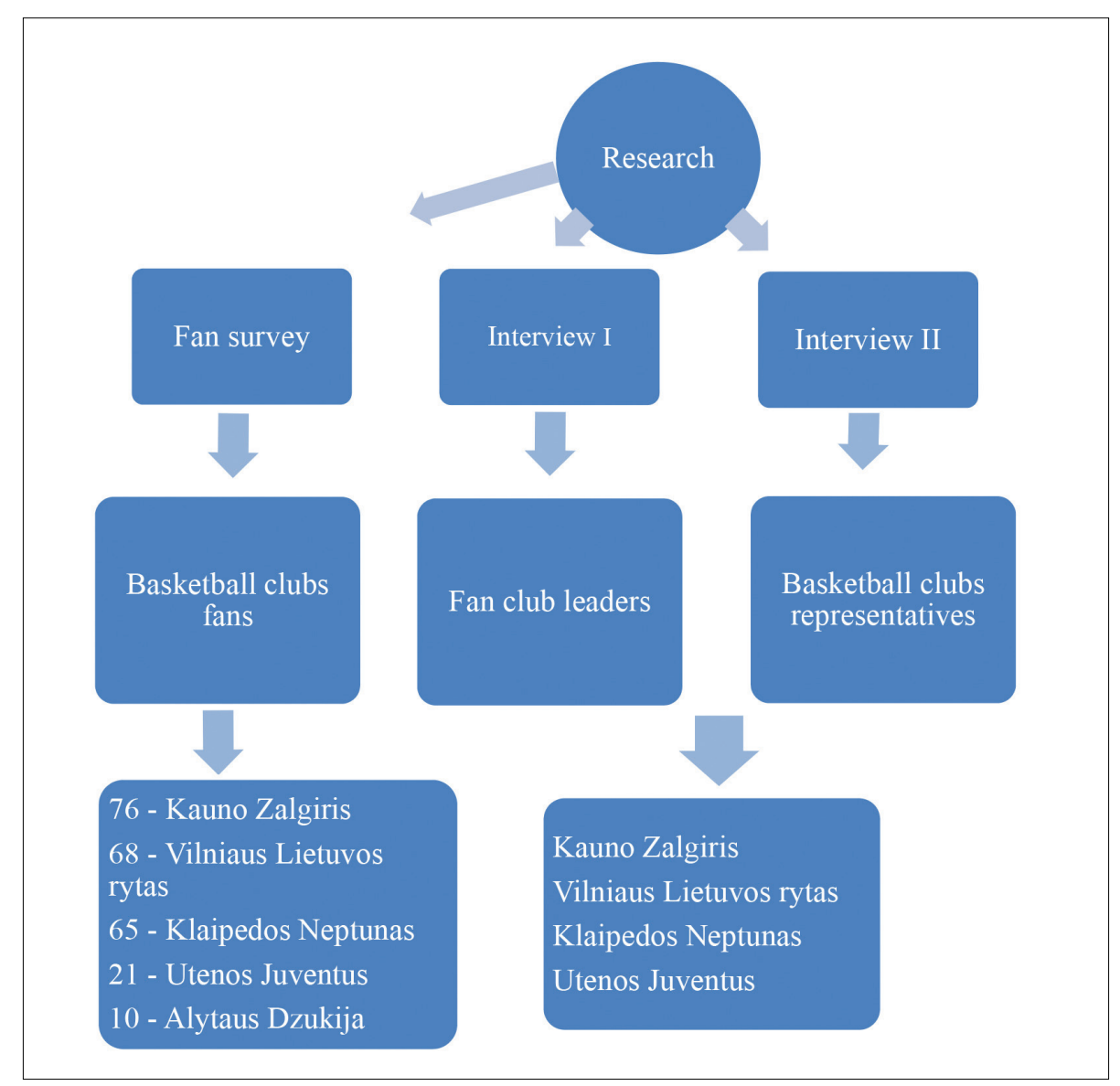


the roof of basketball and to reduce violence by increasing the understanding and empathy between them. The project was implemented from January 2015 until the end of 2016. The project involved Basketball Federations in Turkey, Spain, Croatia, Bulgaria and Lithuania.

The study consisted of 3 phases: survey, semistructured interview I, semi-structured interview II.

Survey. The questionnaire was designed in order to clarify fans' social behavioural patterns, to identify the main factors inducing fans aggression and how it manifests. The authors of the questionnaire were Bulgarian National Sports Academy professor Ivan Sandanski and colleagues (2016). The survey was carried out in 2015, September and October. Target research Group involved fans of five basketball clubs.

Based on the Paniotto formula, 240 fans representing 5 Lithuanian basketball clubs were chosen for the study. The questionnaire consisted of 28 closed questions

Interview I. The main purpose of the interview was to identify the main factors affecting aggression of fans and what actions clubs take in order to prevent fan aggression. The study interviewed representatives of 4 Lithuanian basketball clubs (Kauno Zalgiris, Vilniaus Lietuvos rytas, Klaipedos Neptunas, Utenos Juventus). Each of the club representatives were asked 7 questions, each interview lasted up to 30 minutes. During the interviews, 8 representatives were interviewed, each of them was given 17 questions.

Interview II. Interviews with basketball clubs' representatives were conducted in November and December of 2016 at the end of the project "Fans against violence". Interviews were conducted with the purpose to establish the outcome of the project. The interview included 9 open questions. Interview questions were sent by e-mail to 4 basketball clubs' representatives.

\section{RESULTS}

Survey. A total of 240 questionnaires were received representing 5 different fan clubs. As it can be seen in Figure 4, it was mostly "Kauno Zalgiris" club fans (76).

Most of the respondents were male, majority of them were 20-24 years old. The majority of respondents were official fan club members, most of them became fan club members encouraged by the other devoted fans. The survey revealed the reasons why fans attended matches. One of the most common reasons was "I have fun", this option chosen by $13.5 \%$ of respondents, and "I like the atmosphere in the arena" (11.6\%). The majority of the fans asked about ways they supported their team said "I attend the home games of the team" (19.1\%) and "I wear the colours and the symbols of the team" (17.1\%). The majority of respondents, when asked about main reasons to see the other team fans as rivals, argued that that was determined by a feud between the cities (27.6\%) and the clubs (27.4\%). The main reasons for aggressive and violent behaviour of the fans during the basketball games can be distinguished as follows: provocations and offensive chants of the fans of the other team (15.0\%) and alcohol consumption (11.4\%). Although it considered that alcohol consumption is one of the main reasons for promoting fans aggression, only a small percentage of the respondents were strongly against the consumption of alcohol (7.0\%). Meanwhile, the majority of respondents (35.0\%) answered "It is acceptable only if it is occasional".

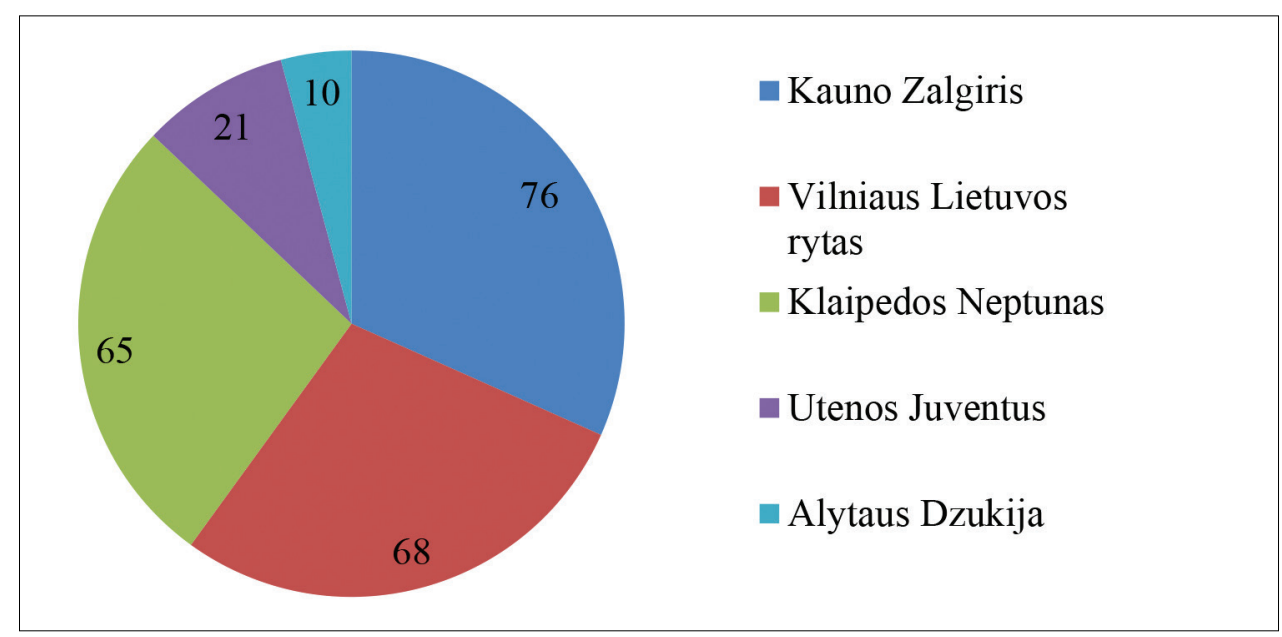


Interview I. It was found during the interview that two different fan groups dominated in the largest Lithuanian basketball fan clubs - youth (students, etc.) and elder persons (businessmen, employees, etc.). the interview clarified predominant attitudes to the fans in Lithuania (Figure 5).

During interviews with representatives of clubs and fan leaders it was possible to distinguish the essential factors inducing fans' aggression (Figure 6).

During the interviews preventive measures were suggested which should be taken to reduce conflicts between fans (Figure 7).

Interview II. The main purpose of interview II was to find out the outcome of the project, understand club opinions concerning the image
Figure 5. Predominant attitudes to the fans in Lithuania
Figure 6. The main causes of aggressive fan behaviour
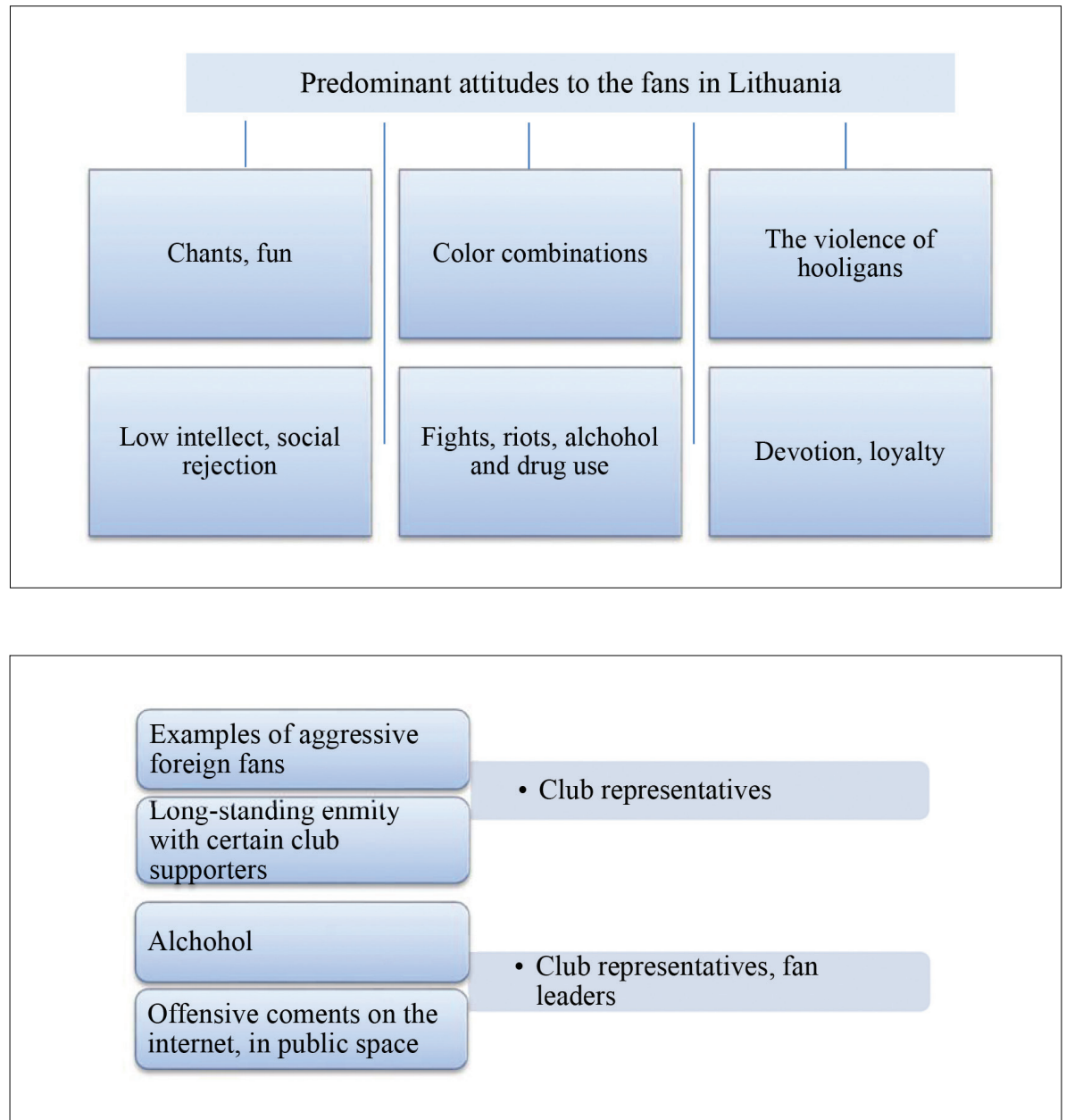

Figure 7. Fan aggression preventive measures

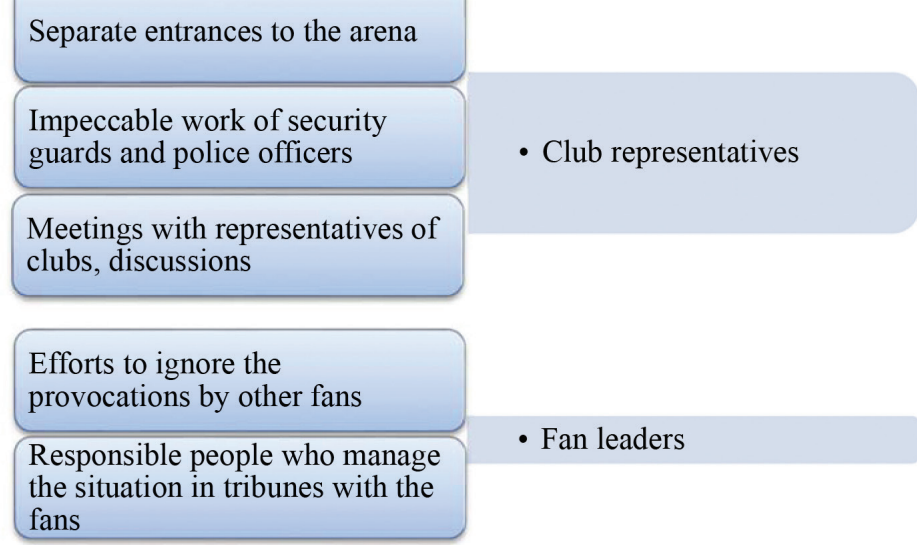

Separate entrances to the arena

Impeccable work of security

Club representatives

fans 
and attitudes towards fans. Summarizing interview II, it can be concluded that the clubs continuously tried to increase the club popularity and cultivate new fans. Clubs admitted that the image was mostly influenced by the results of the team, players' image and communication with supporters and the club's public relations. Project "Fans against violence" was a good start to begin the debate between supporters of different clubs. Basketball clubs admitted that during the project there was not enough time to completely solve the problem, however, they were going to continue to meet with fans to promote tolerance and mutual understanding.

\section{DISCUSSION}

Research results showed that aggressive behaviour of fans was an urgent problem which affected all basketball-related organizations. The research confirms the assumption held by Richelieu and Pons (2011) that basketball fans are not only consumers, but also the co-creators of the final product. All clubs recognize that their image is being developed for the fans.

Literature review showed that the most common reason for riots between fans in Lithuania is historical feud between the cities or the clubs. The survey confirmed assumptions made by the others authors that one of the main reasons for aggressive and violent behaviour is provocations and offensive chants of other fans and alcohol consumption. One thing that was not mentioned in the literature is that Lithuanian fans are influenced by the foreign fans.

Research has proved that fans' behaviour influences all basketball stakeholders. For this reason, each organization's duty is to fight against fans' aggression and to take preventive measures to ensure that in the future this phenomenon would decline.

As noted in the literature, every individual, group of individuals or an organization independently seek it or not, has formed a certain image. Basketball in our country has a special place and it is the most popular sport in Lithuania. Analysis of media leads to presumption that basketball in Lithuania has formed a positive image. Unfortunately, a slightly different situation can be seen in the image which has been formed by the basketball fans. Both because of fans and because of the media, fans have formed "hooligan" image among the society members. As previously noted, basketball club image is directly dependent on the basketball team, sponsors and supporters. So despite the fact that basketball as a sport has formed a positive image, if at least one constituent element (club, supporters, sponsors) has formed a negative image, it will also affect the rest of the components.

The research has shown that there is a lack of information about the influence which fans can make to the sports organization. For this reason future research should focus not only on the causes of aggressive behaviour or the preventive measures, but also on the relationship between the fans and the club image.

\section{CONCLUSIONS}

Image is one of the key factors determining the success of any organization. Every organization has some kind of image, but only well planned and systematically developed image will achieve effective results. Unlike other services or goods, consumers, sports consumers tend to use products or services in groups. Sports organizations' image formation is a complex process that is determined by a number of variables, one of them is consumers (fans). The results of the survey confirm the theoretical part of the work. The majority of basketball fans are the 20-24 year-old males who attend games driven by hedonistic factors. Most of them have become supporters because of other fans. Different team fans' feud goes from generation to generation. Meanwhile, the major cause of aggressive behaviour may be considered provocative actions of the opposing fans and alcohol consumption. Although alcohol consumption is recognized as one of the key incentives for aggressive behaviour, most fans tolerate it. The research leads to the conclusion that fans are an important part of the basketball club's image and their behaviour in some way influences all basketball stakeholders. 


\section{REFERENCES}

Beccarini, C., \& Ferrand, A. (2006). Factors affecting soccer club season ticket holders' satisfaction: The influence of club image and fans' motives. European Sport Management Quarterly, 6(1), 1-22. http://dx.doi. org/10.1080/16184740600799154

Carlson, J., \& O'Cass, A. (2012). Optimizing the online channel in professional sport to create trusting and loyal consumers: The role of the professional sports team brand and service quality. Journal of Sport Management, 26(6), 463-478. doi: 10.1123/jsm.26.6.463

Dima, I. C., \& Vladutescu, S. (2012). The environment of organizational entities and its influence on decisional communication. International Journal of Management Sciences and Business Research, 1(9), 1-11.

Fillis, I., \& Mackay, C. (2014). Moving beyond fan typologies: The impact of social integration on team loyalty in football. Journal of Marketing Management, 30(3, 4), 334-363. doi: 10.1080/0267257X.2013.813575

Hedlund, D. P. (2011). Sport brand community (Doctoral dissertation). USA: The Florida State University.

Hughson, J., \& Free, M. (2006). Paul Willis, cultural commodities, and collective sports fandom. Sociology of Sport Journal, 23, 72-85.

Hunt, K. A., Bristol, T., \& Bashaw, R. E. (1999). A conceptual approach to classifying sports fans. Journal of Services Marketing, 13(6), 439-452. http://dx.doi. org/10.1108/08876049910298720

Kahle, L., Duncan, M., Dalakas, V., \& Aiken, D. (2001). The social values of fans for men's versus women's university basketball. Sport Marketing Quarterly, 10(3), 156-162.

Laczniak, R. N., DeCarlo, T. E., \& Ramaswami, S. N. (2001). Consumers' responses to negative wordof-mouth communication: An attribution theory perspective. Journal of Consumer Psychology, 11(1), 57-73.

Madensen, T., \& Eck, J. E. (2008). Spectator violence in stadiums. USA: U.S. Department of Justice Office of Community Oriented Policing Services.

Merriman, S. B. (1998). Qualitative research and case study applications in education. San Francisco: JosseyBass.

Paul, R. J. (2003). Variations in NHL attendance: The impact of violence, scoring, and regional rivalries.
American Journal of Economics \& Sociology, 62(2), 345-364. doi: 10.1111/1536-7150.t01-2-00003

Pearson, E., (2008). Revisit Elaboration Likelihood Model: How advertising appeals work on attitudinal and behavioral brand loyalty centering around low vs. high-involvement product. European Journal of Social Sciences, 7(1), 126-139.

Rahmati, M. M., \& Momtaz, O. (2013). Does frustration cause aggression? Case study: Soccer fans in Iran. International Research Journal of Applied and Basic Sciences, 4(10), 3028-3035.

Reysen, S., \& Branscombe, N. R. (2010). Fanship and fandom: Comparisons between sport and non-sport fans. Journal of Sport Behavior, 33(2), 176-193.

Richelieu, A., \& Pons, F. (2011). How strong is my sports brand? The case of the Montréal Canadians Hockey Club. Journal of Sponsorship, 4(4), 353-365.

Sandanski, I., Slavchev, I., \& Draganov, G. (2016). "Fans against violence". Project international report. EU: European Commission.

Shoham, A., Dalakas, V., \& Lahav, L. (2015). Consumer misbehavior: Aggressive behavior by sports fans. Services Marketing Quarterly, 36(1), 22-36. doi:10.10 80/15332969.2015.976506

Stake, R. E. (2005). Qualitative case studies. In N. K. Denzin \& Y. S. Lincoln (Eds.), The Sage handbook of qualitative research ( $3 \mathrm{rd}$ ed., pp. 443-466). Thousand Oaks, CA: Sage.

Swenson, S. J. (2012). Unsportsmanlike conduct: The duty placed on stadium owners to protect against fan violence. Marquette Sports Law Review, 23(1), 135-153.

Virvilaite, R., \& Dilys, M. (2015). Formatting sport organization image as a competitive advantage trying to attract more sponsors. Engineering Economics, 21(5), 561-567.

Wann, D. L., Grieve, F. G., Zapalac, R. K., \& Pease, D. G. (2008). Motivational profiles of sport fans of different sports. Sport Marketing Quarterly, 17(1), 6-19.

Yin, R. K. (2003). Case study research design and methods third edition (Applied social research methods series, $5^{\text {th }}$ ed.). Sage Publications.

Zagnoli, P., \& Radicchi, E. (2010). The football-fan community as a determinant stakeholder in value cocreation. Sport in Society, 13(10), 1532-1551. http:// dx.doi.org/10.1080/17430437.2010.520941
Corresponding author Irena Valantinè

Department of Sport Management, Economics and Sociology Lithuanian Sports University

Sporto str. 6, Kaunas LT-44221

Lithuania

Tel. +370 37302662

Email irena.valantine@1su.1t 